Article

\title{
The Kinetics of Total Phenolic Content and Monomeric Flavan-3-ols during the Roasting Process of Criollo Cocoa
}

\author{
Editha Fernández-Romero ${ }^{1}$, Segundo G. Chavez-Quintana ${ }^{2}{ }^{\circledR}$, Raúl Siche ${ }^{3}{ }^{\circledR}$, \\ Efraín M. Castro-Alayo ${ }^{2,4, * \mathbb{D}}$ and Fiorella P. Cardenas-Toro ${ }^{4}$
}

1 Programa Académico de Ingeniería Agroindustrial, Facultad de Ingeniería y Ciencias Agrarias, Universidad Nacional Toribio Rodríguez de Mendoza de Amazonas, Calle Higos Urco 342-350-356, Chachapoyas, Amazonas, Peru; fer.virgo59@gmail.com

2 Instituto de Investigación, Innovación y Desarrollo para el Sector Agrario y Agroindustrial de la Región Amazonas (IIDAA-Amazonas), Facultad de Ingeniería y Ciencias Agrarias, Universidad Nacional Toribio Rodríguez de Mendoza de Amazonas, Calle Higos Urco 342-350-356, Chachapoyas, Amazonas, Peru; segundo.quintana@untrm.edu.pe

3 Facultad de Ciencias Agropecuarias, Universidad Nacional de Trujillo, Av. Juan Pablo II s/n, Ciudad Universitaria, Trujillo 13001, Peru; rsiche@unitru.edu.pe

4 Sección de Ingeniería Industrial, Departamento de Ingeniería, Pontificia Universidad Católica del Perú, Av. Universitaria 1801, San Miguel 150136, Lima 32, Peru; fcardenas@pucp.pe

* Correspondence: efrain.castro@untrm.edu.pe or efrain.castro@pucp.edu.pe; Tel.: +51-986-376-463

Received: 27 November 2019; Accepted: 15 January 2020; Published: 9 February 2020

\begin{abstract}
Cocoa beans are the main raw material for the manufacture of chocolate and are currently gaining great importance due to their antioxidant potential attributed to the total phenolic content (TPC) and the monomeric flavan-3-ols (epicatechin and catechin). The objective of this study was to determine the degradation kinetics parameters of TPC, epicatechin, and catechin during the roasting process of Criollo cocoa for 10, 20, 30, 40, and $50 \mathrm{~min}$ at 90, 110, 130, 150, 170, 190, and $200{ }^{\circ} \mathrm{C}$. The results showed a lower degradation of TPC $(10.98 \pm 6.04 \%)$ and epicatechin $(8.05 \pm 3.01 \%)$ at $130{ }^{\circ} \mathrm{C}$ and $10 \mathrm{~min}$ of roasting, while a total degradation of epicatechin and a $92.29 \pm 0.06 \%$ degradation of TPC was obtained at $200{ }^{\circ} \mathrm{C}$ and $50 \mathrm{~min}$. Reaction rate constant $(k)$ and activation energy $\left(E_{a}\right)$ were $0.02-0.10 \mathrm{~min}^{-1}$ and $24.03 \mathrm{~J} / \mathrm{mol}$ for TPC and $0.02-0.13 \mathrm{~min}^{-1}$ and $22.51 \mathrm{~J} / \mathrm{mol}$ for epicatechin, respectively. Degradation kinetics of TPC and epicatechin showed first-order reactions, while the catechin showed patterns of formation and degradation.
\end{abstract}

Keywords: roasting; catechin; epicatechin; total phenolic content; Criollo cocoa; kinetic

\section{Introduction}

Cocoa beans, the seeds of the tree Theobroma cacao L., are the key raw material for chocolate production [1]. Criollo is the finest variety of cocoa [2]. Its seeds are aromatic, mild tasting, and with low bitterness: they represent the ideal raw material for a quality chocolate $[1,3]$. For obtaining chocolate from cocoa beans, one very important stage in the process is the roasting [4], which results in the production of desirable flavor and aroma compounds, as well as color changes [5]. The temperature and duration of roasting substantially affected the character in chemical and physical changes of cocoa beans [6].

Cocoa and chocolate have recently gained much attention due to their potential benefits in human health [1,7-10] and have recently become the target of increased scientific research due to their health promoting properties [11]. Cocoa, from a therapeutic viewpoint, is important due to the high 
concentrations of polyphenols as antioxidants [12]. These health effects have been assumed to be associated with the presence of polyphenols, among which are monomeric flavan-3-ols: epicatechin and catechin [5,13-16]. The beneficial effects of cocoa polyphenols to human health are, among others, the scavenge of free radicals and prevention of damage to DNA, the chelation of metals, vasoprotective effects, improvements in endothelial function, anti-inflammatory effects, the amelioration of insulin resistance, and anticarcinogenic effects, among others [13,17-21]. Cocoa is a rich source of polyphenolic compounds and may account for $12-18 \%$ of the dry mass of the beans [5]. Typically, polyphenols are sensitive to heat during the process, especially under a high temperature environment, i.e., roasting and drying [22,23]. Additionally, roasting influences the alteration of bioactive compounds [24]. In particular, the roasting process leads to the loss or modification of flavanols, which leads to a $14 \%$ loss of the total phenolic content (TPC), as well as the epimerization of epicatechin to catechin [25-32].

Kinetic modeling can provide a deeper understanding of the changes that occur during thermal processing controlling and food quality optimization [33,34]. Since these roasting techniques were introduced to the chocolate industry, the roasting time and temperature have been studied, applying designs or models that allow for a proper assessment of the process [35]. Various studies have been reported on the effect of roasting on cocoa nibs' coloration, physical/chemical changes $[4,5,8,16,23,25,36]$, flavor changes [37], and the kinetics of polyphenol degradation during drying [12,28,38]; however, studies on the kinetics of the polyphenol and monomeric flavan-3-ol degradation of Criollo cocoa during the roasting process are scarce, so the aim of the present study was to understand this degradation and determine the kinetic parameters.

\section{Materials and Methods}

\subsection{Materials}

Approximately $14 \mathrm{~kg}$ of dried fermented cocoa beans of Criollo variety were obtained directly from Multi-Service Cooperative APROCAM in the Bagua province, Amazon region, Perú.

\subsection{Chemicals and Standards}

Methanol HPLC grade (JT Baker, Deventer, The Netherlands), Folin-Ciocalteu's phenol reagent, gallic acid, sodium carbonate, $\geq 98 \%$ (-)-epicatechin (HPLC) from green tea, $\geq 97 \%$ (-)-catechin (HPLC) from green tea, and $\geq 90 \%$ petroleum ether were purchased from Sigma Aldrich (Diessenhofen, Germany).

\subsection{Roasting Process}

Samples of cocoa bean were subjected to different treatments of time and temperature as conditions of the roasting process. Prior to the roast, the beans were selected according to their size, choosing beans of uniform size. Criollo cocoa samples (100 g) were roasted in a roaster (IMSA, ERTC-51, Lima, Perú) in the Agroindustry Plant Pilot at Universidad Nacional Toribio Rodríguez de Mendoza de Amazonas (UNTRM), Perú.

\subsection{Chemical Analysis}

\subsubsection{Methanolic Extraction of Phenolic Compounds and Monomeric Flavan-3-ols}

According to Summa et al. [29] regarding some modifications, three cocoa beans were ground in a pestle from each sample. The powder was defatted by extraction with petroleum ether and centrifuged using a centrifuge (MPW Med Instruments, MPW-51, Warszawa, Poland) at $3000 \mathrm{rpm}$ for $15 \mathrm{~min}$ at room temperature. The supernatant was then discarded. Fresh petroleum ether was added and then centrifuged (four times). The resulting defatted material was air dried at room temperature. Methanol extraction based on the methodology used by Jonfia-Essien et al. [30] with some modifications was performed, and $0.5 \mathrm{~g}$ of defatted cocoa powder was homogenized in $25 \mathrm{~mL}$ of $80 \%$ methanol for $30 \mathrm{~min}$ 
in a magnetic stirrer and then filtered in a vacuum filter. This methanolic extract was used for the determination of both TPC and monomeric flavan-3-ols.

\subsubsection{Total Phenolic Content}

The TPC of the Criollo cocoa beans was determined following the procedures of Singleton et al. [31] and Hu et al. [7]. Diluted extract $(0.1 \mathrm{~mL})$ or blank $(0.1 \mathrm{~mL}$ deionized water $)$ was mixed with $7.9 \mathrm{~mL}$ water and $0.5 \mathrm{~mL}$ of Folin-Ciocalteu reagent for $5 \mathrm{~min}$ at $22{ }^{\circ} \mathrm{C}$. Next, $1.5 \mathrm{~mL}$ of saturated sodium carbonate solution was added. Reagents were mixed thoroughly by vigorous shaking for $10 \mathrm{~s}$ by hand. The mixture was incubated in the dark at $22{ }^{\circ} \mathrm{C}$ for $2 \mathrm{~h}$ before determination of the absorbance at $765 \mathrm{~nm}$ using an UV/Visible spectrophotometer (Unico, S2100, Dayton, NJ, USA). Gallic acid in 70\% methanol was diluted $(2-16 \mathrm{mg} / \mathrm{L})$ to create a calibration curve. TPC is expressed as $\mathrm{mg}$ of gallic acid equivalents/g defatted cocoa bean (mg GAE/gdf).

\subsubsection{Quantification of Epicatechin and Catechin of the Methanolic Extract}

Quantification of epicatechin and catechin followed the procedures of Wang et al. [39] with some modifications in a high performance liquid chromatography system (HPLC) (Lachrom Elite, Hitachi, Japan) equipped with a UV-Vis detector (Hitachi, Lachrom Elite L-2420, Wako, Japan) and isocratic pump (Hitachi, Lachrom Elite L-2130, Japan). The column used was a C18 $150 \times 4.6 \mathrm{~mm}, 5 \mu \mathrm{m}$ (Merck, Purospher RP-18 endcapped, Darmstadt, Germany). The mobile phase was methanol/water/orthophosphoric acid (20/79.9/0.1), and the flow rate was $1 \mathrm{~mL} / \mathrm{min}$. Absorption wavelength was selected at $210 \mathrm{~nm}$. The sample injection volume was $20 \mu \mathrm{L}$. Chromatographic peaks in the samples were identified by comparing their retention time and UV spectrum with those of the reference standards. A standard graph for each component was prepared by plotting concentration versus area. Quantification was carried out from integrated peak areas of the sample and corresponding standard graphs, and the epic/cat ratios of epicatechin and catechin concentrations were obtained.

\subsubsection{TPC and Monomeric Flavan-3-ol Degradation}

According to Martins et al. [40], the degradation was then calculated according to the following formula:

$$
\% \text { degradation }=\left(\frac{X_{\text {control }}-X_{t}}{X_{\text {control }}}\right) * 100
$$

where $X_{\text {control }}$ is the TPC, epicatechin, or catechin concentration in the control sample (unroasted cocoa bean), and $X_{t}$ is the TPC, epicatechin, or catechin concentration at time $t$.

\subsection{Experimental Desing for Kinetics of TPC and Monomeric Flavan-3-ols}

Samples (100 g) in triplicate of Criollo cocoa beans were roasted for each combination of time and temperature $\left(10,20,30,40\right.$, and $50 \mathrm{~min}$ at $90,110,130,150,170,190$, and $\left.200{ }^{\circ} \mathrm{C}\right), 105$ samples were obtained. Means and standard deviations were calculated. The temperature and time values used were defined according to the published literature. Fitting procedures (Matlab 2014) were used to determine the reaction rate constants for TPC, epicatechin, and catechin. The general kinetic models of zero-, first-, and second-order reactions were used, presented in Equations (2)-(4), respectively [41].

$$
\begin{gathered}
{[A]_{0}-[A]=k t} \\
{[A]=[A]_{0} \exp (-k t)} \\
\frac{1}{[A]}-\frac{1}{[A]_{0}}=k t
\end{gathered}
$$


$k\left(\mathrm{~min}^{-1}\right)$ is the reaction rate constant at temperature $\mathrm{T} ; t$ is the reaction time (min); $[A]_{0}$ and $[A]$ are the initial (control sample) and final amounts of TPC, epicatechin or catechin, respectively, at different times $t$ and temperatures.

The final fitting models were obtained by matching and analyzing the initial models obtained by Matlab software with general equations of zero-, first-, and second-order reactions presented in Equations (2)-(4), respectively. The effect of temperature was evaluated by means of the Arrhenius equation.

$$
k=k_{0} * e^{\left(-E_{a} / R T\right)} .
$$

The activation energy $E_{a}$ for the formation of each parameter was determined by linear regression of $L n k$ curve versus $1 / T$ with Equation (6).

$$
L n k=L n k_{0}-E_{a} / R T
$$

$E_{a}(\mathrm{~J} / \mathrm{mol})$ is the apparent activation energy, $R(8.3145 \mathrm{~J} / \mathrm{mol} . \mathrm{K})$ is the universal gas constant, $k$ is the reaction rate constant, and $k_{0}$ is the pre-exponential factor.

\subsection{Statistical Analysis}

The results were compared using one-factor analysis of variance (ANOVA) followed by the Tukey test. Previously, Dixon's Q test, for the identification and rejection of outliers, was used. Statistical analyses were carried out in Minitab 17 software.

\section{Results}

\subsection{Effect of Roasting on Monomeric Flavan-3-ols and TPC}

The TPC, epicatechin, and catechin concentration and the epi/cat ratio of the unroasted (control sample) Criollo cocoa beans were $110.98 \pm 1.43 \mathrm{mg} \mathrm{GAE} / \mathrm{gdf}, 30.29 \pm 1.0 \mathrm{mg} / \mathrm{gdf}, 2.71 \pm 0.13 \mathrm{mg} / \mathrm{gdf}$, and $11.20 \pm 0.40$, respectively (Table 1 ). These values served as a starting point for the study of degradation. The TPC and epicatechin values and the epi/cat ratios of the treatments were lower than the control sample. Some results show that the concentration of epicatechin in some cases increased. During the roasting process, the epi/cat ratio was reduced as the process temperature increased. Considering a time of $10 \mathrm{~min}$, the epi/cat ratio was reduced from $6.08 \pm 0.96$ when heated at $90{ }^{\circ} \mathrm{C}$ to $3.20 \pm 0.68$ at $200{ }^{\circ} \mathrm{C}$. Table 1 shows that epicatechin degradation reached $100 \%$ when Criollo cocoa beans were roasted for $50 \mathrm{~min}$ at 190 or $200{ }^{\circ} \mathrm{C}$, while TPC did not reach full degradation at any temperature or time. The opposite happened with catechin, which showed patterns of formation. The values in bold indicate that there was formation instead of degradation. 
Table 1. Concentration and degradation of TPC and monomeric flavan-3-ols, epi/cat ratios, and the formation of catechin.

\begin{tabular}{|c|c|c|c|c|c|c|c|c|}
\hline \multirow{2}{*}{$\mathrm{T}\left({ }^{\circ} \mathrm{C}\right)$} & \multirow{2}{*}{$\begin{array}{l}\text { Time } \\
\text { (min) }\end{array}$} & \multicolumn{3}{|c|}{ Concentration $^{1}$} & \multirow{2}{*}{ Epi/Cat Ratio ${ }^{1}$} & \multicolumn{3}{|c|}{ Degradation $^{1}(\%)$} \\
\hline & & $\begin{array}{c}\text { TPC (mg } \\
\text { GAE/gdf) }\end{array}$ & $\begin{array}{c}\text { Epicatechin } \\
\text { (mg/gdf) }\end{array}$ & $\begin{array}{l}\text { Catechin } \\
\text { (mg/gdf) }\end{array}$ & & TPC & Epicatechin & Catechin $^{2}$ \\
\hline Control & 0 & $110.98 \pm 1.43^{\mathrm{a}}$ & $30.29 \pm 1.09^{\mathrm{a}}$ & $2.71 \pm 0.13^{\mathrm{a}}$ & $11.20 \pm 0.40^{\mathrm{a}}$ & & & \\
\hline \multirow[t]{5}{*}{90} & 10 & $54.60 \pm 10.86^{\mathrm{b}}$ & $14.97 \pm 1.45^{\mathrm{b}}$ & $2.48 \pm 0.14^{\mathrm{ab}}$ & $6.08 \pm 0.96^{\mathrm{b}}$ & $50.84 \pm 9.47^{\mathrm{a}}$ & $50.41 \pm 6.61^{\mathrm{a}}$ & $8.31 \pm 5.43^{\mathrm{a}}$ \\
\hline & 20 & $72.70 \pm 7.44^{\mathrm{b}}$ & $17.78 \pm 3.13^{b}$ & $2.48 \pm 0.05^{\mathrm{ab}}$ & $7.20 \pm 1.37^{b}$ & $34.44 \pm 7.46^{\mathrm{a}}$ & $41.25 \pm 10.23^{\mathrm{a}}$ & $8.31 \pm 6.24^{\mathrm{a}}$ \\
\hline & 30 & $45.10 \pm 7.61^{b}$ & $11.78 \pm 1.22^{\mathrm{b}}$ & $2.20 \pm 0.11^{\mathrm{b}}$ & $5.35 \pm 0.32^{b}$ & $59.41 \pm 6.47^{\mathrm{a}}$ & $61.07 \pm 4.13^{\mathrm{a}}$ & $18.69 \pm 3.99^{a}$ \\
\hline & 40 & $62.10 \pm 19.80^{\mathrm{b}}$ & $12.92 \pm 4.89^{\mathrm{b}}$ & $2.22 \pm 0.28^{b}$ & $5.93 \pm 2.62^{b}$ & $43.90 \pm 18.7^{\mathrm{a}}$ & $57.0 \pm 17.7^{\mathrm{a}}$ & $18.25 \pm 6.22^{\mathrm{a}}$ \\
\hline & 50 & $51.58 \pm 7.44^{\mathrm{b}}$ & $13.75 \pm 2.92^{\mathrm{b}}$ & $2.48 \pm 0.04^{\mathrm{ab}}$ & $5.55 \pm 1.24^{\mathrm{b}}$ & $53.46 \pm 7.29^{a}$ & $54.78 \pm 8.05^{\mathrm{a}}$ & $8.08 \pm 5.82^{\mathrm{a}}$ \\
\hline \multirow[t]{5}{*}{110} & 10 & $68.54 \pm 4.05^{c}$ & $27.24 \pm 0.53^{c}$ & $2.60 \pm 0.07^{\mathrm{cd}}$ & $10.50 \pm 0.36^{\mathrm{c}}$ & $38.21 \pm 4.44^{\mathrm{c}}$ & $10.02 \pm 2.08^{\mathrm{d}}$ & $2.22 \pm 1.45^{\mathrm{d}}$ \\
\hline & 20 & $60.84 \pm 5.59^{\mathrm{cd}}$ & $15.36 \pm 0.47^{\mathrm{d}}$ & $2.67 \pm 0.21^{\mathrm{c}}$ & $5.78 \pm 0.50^{\mathrm{d}}$ & $45.14 \pm 5.72^{\mathrm{bc}}$ & $49.20 \pm 3.07^{c}$ & $7.78 \pm 2.00^{\mathrm{cd}}$ \\
\hline & 30 & $52.25 \pm 3.86^{\mathrm{d}}$ & $11.47 \pm 0.46^{\mathrm{e}}$ & $2.28 \pm 0.08^{\mathrm{de}}$ & $5.05 \pm 0.28^{\mathrm{de}}$ & $52.91 \pm 3.59^{\mathrm{b}}$ & $62.10 \pm 1.50^{\mathrm{b}}$ & $15.79 \pm 4.65^{\mathrm{bc}}$ \\
\hline & 40 & $48.14 \pm 6.12^{\mathrm{d}}$ & $8.28 \pm 1.36^{\mathrm{e}}$ & $2.33 \pm 0.18^{\text {cde }}$ & $3.54 \pm 0.31^{f}$ & $56.58 \pm 5.95^{\mathrm{b}}$ & $72.53 \pm 5.49^{\mathrm{b}}$ & $13.59 \pm 8.53^{\mathrm{bcd}}$ \\
\hline & 50 & $58.92 \pm 6.57^{\mathrm{cd}}$ & $8.22 \pm 2.37^{e}$ & $2.06 \pm 0.12^{\mathrm{e}}$ & $3.96 \pm 0.97^{\mathrm{ef}}$ & $46.88 \pm 6.30^{\mathrm{bc}}$ & $72.77 \pm 8.31^{\mathrm{b}}$ & $24.00 \pm 3.58^{b}$ \\
\hline \multirow[t]{5}{*}{130} & 10 & $98.85 \pm 7.79^{\mathrm{e}}$ & $28.74 \pm 0.94^{\mathrm{f}}$ & $3.01 \pm 0.03^{\mathrm{f}}$ & $9.55 \pm 0.39 g$ & $10.98 \pm 6.04^{\mathrm{f}}$ & $8.05 \pm 3.01^{\mathrm{e}}$ & $11.46 \pm 4.71^{\mathrm{e}}$ \\
\hline & 20 & $52.24 \pm 3.68^{\mathrm{f}}$ & $11.21 \pm 1.24 \mathrm{~g}$ & $2.69 \pm 0.47^{\mathrm{f}}$ & $4.20 \pm 0.26^{\mathrm{h}}$ & $52.93 \pm 3.24^{\mathrm{e}}$ & $62.87 \pm 5.25^{\mathrm{d}}$ & $14.22 \pm 6.08^{\mathrm{e}}$ \\
\hline & 30 & $35.34 \pm 2.19 \mathrm{~g}$ & $9.47 \pm 1.01^{\mathrm{gh}}$ & $2.62 \pm 0.23^{\mathrm{f}}$ & $3.66 \pm 0.67^{\mathrm{hi}}$ & $68.14 \pm 2.34^{\mathrm{d}}$ & $68.77 \pm 2.57^{\mathrm{cd}}$ & $5.30 \pm 4.23^{\mathrm{e}}$ \\
\hline & 40 & $44.35 \pm 7.73^{\mathrm{fg}}$ & $10.46 \pm 1.46^{g}$ & $3.30 \pm 0.36^{\mathrm{f}}$ & $3.23 \pm 0.81^{\mathrm{hi}}$ & $60.01 \pm 7.15^{\mathrm{de}}$ & $65.40 \pm 5.08^{\mathrm{d}}$ & $18.62 \pm 7.50^{\mathrm{e}}$ \\
\hline & 50 & $38.43 \pm 3.98^{\mathrm{fg}}$ & $6.98 \pm 1.01^{\mathrm{h}}$ & $2.95 \pm 0.22^{\mathrm{f}}$ & $2.36 \pm 0.20^{\mathrm{i}}$ & $65.40 \pm 3.16^{\mathrm{de}}$ & $76.99 \pm 2.78^{\mathrm{c}}$ & $9.08 \pm 7.50^{\mathrm{e}}$ \\
\hline \multirow[t]{5}{*}{150} & 10 & $46.71 \pm 7.84^{\mathrm{h}}$ & $11.25 \pm 2.11^{\mathrm{i}}$ & $2.62 \pm 0.24^{g}$ & $4.26 \pm 0.41^{j}$ & $57.85 \pm 7.61^{\mathrm{h}}$ & $62.70 \pm 8.19^{\mathrm{h}}$ & $8.66 \pm 0.15^{f}$ \\
\hline & 20 & $48.78 \pm 8.12^{\mathrm{h}}$ & $8.70 \pm 0.70^{\mathrm{ij}}$ & $3.49 \pm 0.68^{g}$ & $2.59 \pm 0.73^{k}$ & $56.07 \pm 7.02^{\mathrm{h}}$ & $71.29 \pm 1.29^{9 h}$ & $32.90 \pm 25.60^{\mathrm{f}}$ \\
\hline & 30 & $31.32 \pm 2.25^{\mathrm{i}}$ & $6.32 \pm 0.53^{\mathrm{jk}}$ & $3.79 \pm 0.75^{g}$ & $1.70 \pm 0.25^{\mathrm{kl}}$ & $71.80 \pm 1.72 \mathrm{~g}$ & $79.14 \pm 1.51^{\mathrm{fg}}$ & $39.60 \pm 21.10^{\mathrm{f}}$ \\
\hline & 40 & $31.27 \pm 2.17^{\mathrm{i}}$ & $5.72 \pm 0.12^{\mathrm{k}}$ & $3.64 \pm 0.10^{g}$ & $1.57 \pm 0.07^{\mathrm{kl}}$ & $71.81 \pm 2.18^{g}$ & $81.11 \pm 0.84^{\mathrm{fg}}$ & $34.61 \pm 8.41^{\mathrm{f}}$ \\
\hline & 50 & $28.22 \pm 1.32^{\mathrm{i}}$ & $4.27 \pm 0.68^{\mathrm{k}}$ & $3.01 \pm 0.35^{g}$ & $1.41 \pm 0.08^{1}$ & $74.57 \pm 1.37 \mathrm{~g}$ & $85.95 \pm 1.81^{\mathrm{f}}$ & $11.05 \pm 8.82^{f}$ \\
\hline \multirow[t]{5}{*}{170} & 10 & $42.10 \pm 7.56^{j}$ & $12.33 \pm 2.33^{1}$ & $3.48 \pm 0.98^{\mathrm{hij}}$ & $0.08 \pm 0.02^{\text {no }}$ & $62.12 \pm 6.39 j$ & $59.44 \pm 6.36^{\mathrm{k}}$ & $11.58 \pm 0.01^{\mathrm{h}}$ \\
\hline & 20 & $33.43 \pm 7.28^{\mathrm{k}}$ & $6.75 \pm 0.77^{\mathrm{m}}$ & $4.66 \pm 0.31^{\mathrm{hi}}$ & $0.10 \pm 0.02^{\mathrm{n}}$ & $69.84 \pm 6.81^{\mathrm{ij}}$ & $77.75 \pm 1.80^{\mathrm{j}}$ & $72.34 \pm 12.0^{\text {gh }}$ \\
\hline & 30 & $31.50 \pm 6.43^{\mathrm{k}}$ & $5.41 \pm 0.69^{\mathrm{mn}}$ & $5.15 \pm 1.11^{\mathrm{h}}$ & $0.17 \pm 0.05^{\mathrm{m}}$ & $71.66 \pm 5.50^{\mathrm{ij}}$ & $82.11 \pm 2.36^{\mathrm{ij}}$ & $84.90 \pm 37.90^{\mathrm{g}}$ \\
\hline & 40 & $31.33 \pm 7.40^{\mathrm{j}}$ & $4.16 \pm 0.59^{\mathrm{mn}}$ & $3.85 \pm 0.66^{\mathrm{hij}}$ & $0.12 \pm 0.02^{\mathrm{mn}}$ & $71.82 \pm 6.36^{\mathrm{ij}}$ & $86.26 \pm 1.77^{\mathrm{ij}}$ & $43.00 \pm 30.30^{\mathrm{gh}}$ \\
\hline & 50 & $19.54 \pm 1.05^{\mathrm{k}}$ & $3.12 \pm 0.18^{\mathrm{n}}$ & $3.19 \pm 0.42^{\mathrm{ij}}$ & $0.11 \pm 0.01^{\mathrm{mn}}$ & $82.40 \pm 0.89^{\mathrm{i}}$ & $89.70 \pm 0.77^{\mathrm{i}}$ & $22.19 \pm 14.41^{\mathrm{h}}$ \\
\hline \multirow[t]{5}{*}{190} & 10 & $41.13 \pm 8.69^{1}$ & $11.61 \pm 4.88^{\circ}$ & $3.67 \pm 0.91^{1}$ & $3.35 \pm 1.62^{\mathrm{P}}$ & $62.95 \pm 7.70^{1}$ & $61.93 \pm 15.42^{\mathrm{m}}$ & $42.3 \pm 29.40^{\mathrm{ij}}$ \\
\hline & 20 & $38.17 \pm 6.69^{1}$ & $5.70 \pm 0.50^{\mathrm{P}}$ & $4.87 \pm 0.28^{\mathrm{k}}$ & $1.18 \pm 0.17 q$ & $65.63 \pm 5.75^{1}$ & $81.20 \pm 0.99^{1}$ & $80.50 \pm 17.40^{\mathrm{i}}$ \\
\hline & 30 & $21.35 \pm 4.45^{\mathrm{m}}$ & $3.11 \pm 0.60^{\mathrm{pq}}$ & $2.77 \pm 0.25^{\mathrm{Im}}$ & $1.11 \pm 0.12^{q}$ & $80.79 \pm 3.80^{\mathrm{k}}$ & $89.70 \pm 2.32^{\mathrm{kl}}$ & $7.32 \pm 6.32^{\mathrm{j}}$ \\
\hline & 40 & $19.81 \pm 2.11^{\mathrm{m}}$ & $2.43 \pm 0.13^{\mathrm{pq}}$ & $2.67 \pm 0.27 \mathrm{~lm}$ & $0.92 \pm 0.10^{q}$ & $82.17 \pm 1.72^{\mathrm{k}}$ & $91.97 \pm 0.23^{\mathrm{kl}}$ & $9.97 \pm 3.21^{j}$ \\
\hline & 50 & $12.31 \pm 1.36^{\mathrm{m}}$ & $0.00 \pm 0.00 q$ & $2.05 \pm 0.07^{\mathrm{m}}$ & $0.00 \pm 0.00^{q}$ & $88.91 \pm 1.27^{\mathrm{k}}$ & $100.00 \pm 0.00^{\mathrm{k}}$ & $23.96 \pm 6.02^{\mathrm{j}}$ \\
\hline \multirow{5}{*}{200} & 10 & $33.23 \pm 2.44^{\mathrm{n}}$ & $8.10 \pm 0.88^{r}$ & $3.20 \pm 0.68^{n}$ & $2.64 \pm 0.83^{r}$ & $70.04 \pm 2.60^{\circ}$ & $73.21 \pm 3.58^{\mathrm{P}}$ & $21.89 \pm 14.12^{\mathrm{k}}$ \\
\hline & 20 & $17.33 \pm 3.26^{\circ}$ & $2.42 \pm 0.21^{\mathrm{s}}$ & $2.30 \pm 0.30^{n}$ & $1.06 \pm 0.05^{\mathrm{s}}$ & $84.38 \pm 2.98^{\mathrm{n}}$ & $92.01 \pm 0.39^{\circ}$ & $15.17 \pm 7.86^{\mathrm{k}}$ \\
\hline & 30 & $13.76 \pm 0.53^{\circ \mathrm{p}}$ & $2.32 \pm 0.06^{\mathrm{s}}$ & $2.26 \pm 0.07^{\mathrm{n}}$ & $1.03 \pm 0.03^{\mathrm{s}}$ & $87.60 \pm 0.64^{\mathrm{mn}}$ & $92.34 \pm 0.10^{\circ}$ & $16.56 \pm 1.54^{\mathrm{k}}$ \\
\hline & 40 & $14.41 \pm 1.86^{\circ}$ & $2.53 \pm 0.45^{\mathrm{s}}$ & $2.35 \pm 0.60^{\mathrm{n}}$ & $1.09 \pm 0.09^{\mathrm{st}}$ & $87.00 \pm 1.85^{\mathrm{mn}}$ & $91.61 \pm 1.81^{\circ}$ & $22.29 \pm 10.34^{\mathrm{k}}$ \\
\hline & 50 & $8.56 \pm 0.10^{\mathrm{P}}$ & $0.00 \pm 0.00^{t}$ & $2.13 \pm 0.21^{\mathrm{n}}$ & $0.00 \pm 0.00^{\mathrm{t}}$ & $92.29 \pm 0.06^{\mathrm{m}}$ & $100.00 \pm 0.00^{\mathrm{n}}$ & $21.37 \pm 5.74^{\mathrm{k}}$ \\
\hline
\end{tabular}

${ }^{1}$ Different letters in the same column represent statistically significant differences ( $\left.p \leq 0.05\right)$. At least three replicate samples were analyzed. ${ }^{2}$ Bold values indicate an increase in catechin concentration. 


\subsection{Roasting Kinetics of Monomeric Flavan-3-ols and TPC}

The values obtained from the fitted parameters are given in Table 2. In the case of TPC and epicatechin, the $k$ value increases from $0.02 \pm 0.01 \mathrm{~min}^{-1}$ at $90{ }^{\circ} \mathrm{C}$ to $0.10 \pm 0.05 \mathrm{~min}^{-1}$ at $200{ }^{\circ} \mathrm{C}$, and from $0.02 \pm 0.01 \mathrm{~min}^{-1}$ at $90^{\circ} \mathrm{C}$ to $0.13 \pm 0.04 \mathrm{~min}^{-1}$ at $200{ }^{\circ} \mathrm{C}$, respectively. The kinetic parameters of the catechin are not shown because it corresponds to a combined production and degradation model, which does not correspond to Equations (2), (3), or (4).

Table 2. First-order kinetic parameters fitted for TPC and epicatechin degradation.

\begin{tabular}{ccccccc}
\hline \multirow{2}{*}{$\begin{array}{c}\text { Roasting } \\
\text { Temperature }\left({ }^{\circ} \mathbf{C}\right)\end{array}$} & \multicolumn{3}{c}{ TPC } & \multicolumn{3}{c}{ Epicatechin } \\
\cline { 2 - 7 }$\left(\mathbf{m i n}^{-1}\right)$ & $\boldsymbol{R}^{\mathbf{2}}$ & RMSE & $\boldsymbol{k}\left(\mathbf{m i n}^{-1}\right)$ & $\boldsymbol{R}^{2}$ & RMSE \\
\hline 90 & $0.02 \pm 0.01$ & 0.52 & 18.50 & $0.02 \pm 0.01$ & 0.65 & 4.57 \\
110 & $0.02 \pm 0.01$ & 0.70 & 13.97 & $0.03 \pm 0.01$ & 0.95 & 2.49 \\
130 & $0.03 \pm 0.02$ & 0.87 & 13.08 & $0.03 \pm 0.02$ & 0.86 & 4.31 \\
150 & $0.04 \pm 0.03$ & 0.83 & 14.59 & $0.06 \pm 0.03$ & 0.91 & 3.27 \\
170 & $0.07 \pm 0.03$ & 0.96 & 2.24 & $0.07 \pm 0.03$ & 0.96 & 2.24 \\
190 & $0.06 \pm 0.03$ & 0.92 & 11.35 & $0.09 \pm 0.02$ & 0.99 & 1.05 \\
200 & $0.10 \pm 0.05$ & 0.96 & 9.23 & $0.13 \pm 0.04$ & 0.99 & 1.44 \\
\hline
\end{tabular}

Figure 1 shows that the catechin reaction kinetics could be divided into two order models: one for formation and the other for degradation, where the highest catechin formation $(\mathbf{8 4 . 9 0} \pm \mathbf{3 7 . 9 0 \%})$ was at $170{ }^{\circ} \mathrm{C}$ and $30 \mathrm{~min}$ of roasting.

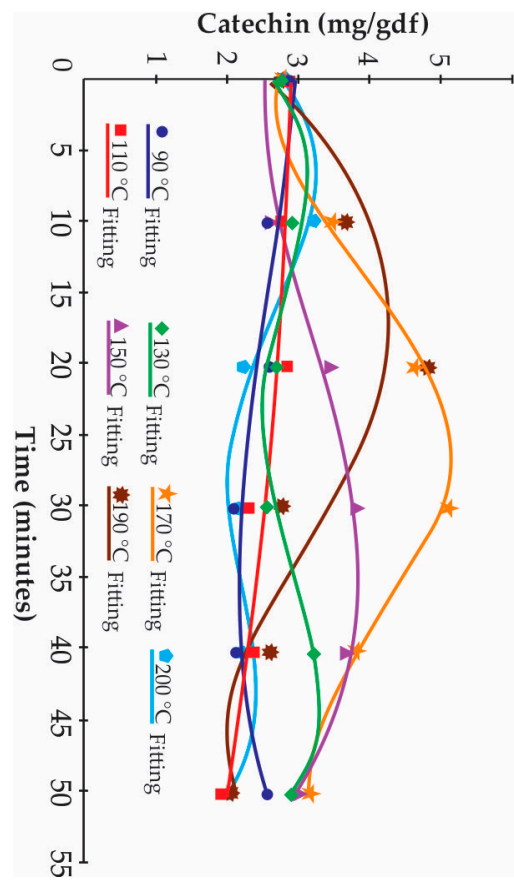

Figure 1. Kinetic of formation and degradation of catechin.

The temperature dependence of the TPC and epicatechin degradation was estimated using the Arrhenius equation expressed in Equation (5). The linear behavior of $L n k$ versus 1/T allowed us to determine $E_{a}$ for TPC and epicatechin of $24.03 \mathrm{~J} / \mathrm{mol}\left(\mathrm{R}^{2}=0.94\right)$ and $22.51 \mathrm{~J} / \mathrm{mol}\left(\mathrm{R}^{2}=0.97\right)$, respectively (Figure 2). The parameters for catechin kinetics were not calculated because it presented a degradation and production pattern, as mentioned above. 


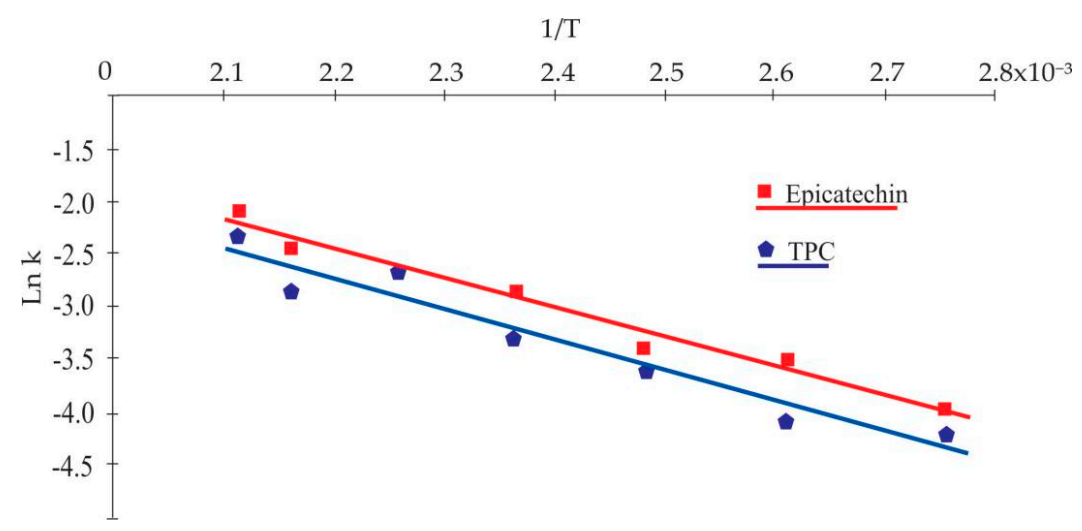

Figure 2. Correlation of $\operatorname{Ln} k$ with $1 / \mathrm{T}$ to obtain the TPC and epicatechin kinetic parameters.

\section{Discussion}

The time and temperature of the roasting process depend on several factors, such as the type of cocoa (Criollo or Forastero) and others [42]. The main type of polyphenols (known for their demonstrated antioxidant and anti-inflammatory properties) in cocoa is flavanols. This family of compounds includes catechin and epicatechin (monomeric species). Epicatechin is the most abundant flavanol in cocoa and accounts for 35\% of the total polyphenolic fraction [43,44] (TPC). In one study made by Kim and Keeney [45], the epicatechin concentrations ranged from 2.66 (Jamaica) to $16.52 \mathrm{mg} / \mathrm{g}$ (Costa Rica) of the defatted sample in cocoa beans of different varieties. The epicatechin and catechin concentrations of the control sample were higher than those found by Kim and Keeney [45] and Payne et al. [32] in fermented cocoa beans (the Forastero variety) from Ivory Coast (epicatechin: $1.69 \pm 0.10$ $\mathrm{mg} / \mathrm{g}$; catechin: $0.08 \pm 0.00 \mathrm{mg} / \mathrm{g}$ ) and Papua New Guinea (epicatechin: $0.78 \pm 0.04 \mathrm{mg} / \mathrm{g}$; catechin: $0.05 \pm 0.00 \mathrm{mg} / \mathrm{g}$ ). These values were higher than those found by Mazor Jolić et al. [46] in Forastero cocoa beans from Ghana (epicatechin: $2.23 \pm 0.6 \mathrm{mg} / \mathrm{g}$; catechin: $0.28 \pm 0.04 \mathrm{mg} / \mathrm{g}$ ). Other studies conducted in Perú on fermented cocoa beans from Tingo María, San Alejandro, and Curimaná presented epicatechin and catechin concentrations of $0.33-5.04 \mathrm{mg} / \mathrm{g}$ and $0.02-0.14 \mathrm{mg} / \mathrm{g}$, respectively [47]. It is known that epicatechin has diverse biological properties (antioxidant, antimicrobial, anti-inflammatory, antitumor, and cardio-protective activity) [48]; thus, the Criollo cocoa beans used in the present study show potential for use in the elaboration of functional foods. It has been postulated that the ratio of epicatechin to catechin (epi/cat) possibly could be associated with the degree of cocoa processing [32,49]. Payne et al. [32] obtained epi/cat ratio values of $20.1 \pm 0.63$ for dry fermented cocoa beans and 3.35 \pm 0.20 at $90^{\circ} \mathrm{C}$ to $0.96 \pm 0.02$ at $120^{\circ} \mathrm{C}$ for roasted beans. Table 1 shows control sample epi/cat ratio values of $11.20 \pm 0.40$; considering $50 \mathrm{~min}$ of roasting, values of $5.55 \pm 1.24$ at $90^{\circ} \mathrm{C}$ to $2.36 \pm 0.20$ at $130{ }^{\circ} \mathrm{C}$ and $0.00 \pm 0.00$ at $200{ }^{\circ} \mathrm{C}$ were obtained. These results demonstrate that roasting at $200{ }^{\circ} \mathrm{C}$ at any time (10 or $50 \mathrm{~min}$ ) is aggressive for epicatechin, so if these parameters are used, the functional properties of chocolate will be lost.

In Table 1 , a roasting time of $50 \mathrm{~min}$ at $90,110,130,150,170,190$, and $200^{\circ} \mathrm{C}$ degraded the TPC to $53.46 \pm 7.29,46.88 \pm 6.30,65.40 \pm 3.16,74.57 \pm 1.37,82.40 \pm 0.89,88.91 \pm 1.27$, and $92.29 \pm 0.06$, respectively; these results are consistent with those obtained by Mazor Jolić et al. [46]. The decrease of TPC is associated with the thermal and oxidative degradation of these compounds [35]. It was proven that, at high temperature, low molecular weight phenolic compounds easily volatilize [50]. Djikeng et al. [50] also observed that the degradation percentage of the TPC also increased with roasting time. In general, more intense roasting conditions result in a greater loss of TPC due to the high redox activity of polyphenols at those conditions $[50,51]$. Epicatechin degraded more than TPC at a higher temperature, obtaining a complete degradation at $200{ }^{\circ} \mathrm{C}$ and $50 \mathrm{~min}$. This is concordant with Stanley et al. [5], who observed the significant effects of roasting time within temperatures up to $190{ }^{\circ} \mathrm{C}$; the levels of epicatechin in Trinitario cocoa (a type of fine cocoa) decreased in a time- and temperature-dependent manner. Significant decreases in Criollo cocoa were observed. Among the monomeric flavan-3-ols, 
epicatechin was identified as the more active compound responsible for the vascular health benefits associated with cocoa and chocolate [52]. Applying treatments of $190-200{ }^{\circ} \mathrm{C}$ results in a total loss of epicatechin, and the healthy properties of the Criollo cacao and its aromatic properties may also be reduced; for this reason, Żyżelewicz et al. [1] and Hurst et al. [36] state that Criollo beans require milder roasting conditions. The roasting temperature is generally in the range from 110 to $120^{\circ} \mathrm{C}$.

The most important reactions occurring with catechins under thermal processing are epimerization, hydrolysis, oxidation, and polymerization; catechin epimerization takes place on two asymmetric carbon atoms in the $C$ ring [53]. In Table 1, catechin shows a particular behavior due to the increase in its concentration (formation) at the beginning of the roasting. The catechin values in bold font shows an increase in its concentration with respect to the control sample (unroasted beans) during the first $10 \mathrm{~min}$ at $130{ }^{\circ} \mathrm{C}(\mathbf{1 1 . 4 6} \mathbf{\pm 4 . 7 1 \%})$, and its formation continues until the first $10 \mathrm{~min}$ at $200{ }^{\circ} \mathrm{C}$ and subsequently degrades to $21.37 \pm 5.74 \%$. The trend of these results is consistent with those obtained by Stanley et al. [5], except that the catechin formation was much higher, showing an increase in catechin concentration $675 \%$ higher than the control (unroasted beans) at $10 \mathrm{~min}$. These results were reported for Trinitario cocoa beans. We can affirm that, in Trinitario cacao, the formation of catechin is much greater than in Criollo cacao, and this applies to the epimerization of epicatechin to catechin $[5,14,25,32,54]$; however, as the treatment continued, its concentration decreased. These results were also found by Żyżelewicz et al. [4] in Forastero cocoa, since after $15 \mathrm{~min}$ of roasting at $135^{\circ} \mathrm{C}$, the content of catechin increased significantly, initiating its degradation. When cocoa beans are progressively roasted at conditions described as low, medium, and high roast conditions ( $160{ }^{\circ} \mathrm{C}$ at 13,20 , and $25 \mathrm{~min}$ ), there is a progressive loss of epicatechin and an increase in catechin with higher roast levels [36,55]. The high temperature-short time (HTST) process induces higher epicatechin epimerization than does the low temperature-long-time (LTLT) process, generating greater amounts of catechin [16,53].

Cocoa consumption is suggested to promote health benefits. The amounts and profiles of monomeric flavanols depend strongly on the bean type, origin, and manufacturing process. Roasting is known as a crucial step in the technical treatment of cocoa, which leads to flavanol losses and modifications, especially the epimerization of epicatechin to catechin [42]. These modifications were fully produced (epimerization) at temperatures of 150,170 , and $190{ }^{\circ} \mathrm{C}$ (Table 1 ). In the manufacture of chocolate, it is necessary to achieve a balance that maintains healthy properties and the development of the aroma that characterizes fine, Criollo cocoa chocolates.

In order to explain the phenomena of TPC and epicatechin degradation, the data were fitted using kinetic models, which are pseudo first-order kinetic reactions coinciding with the majority of food reactions [56]. The term "pseudo" is added with respect to reactions in biological materials, such as food, because the actual reaction mechanism and its kinetics are far more complex [28]. We used seven temperatures in our experiment, allowing us to notice the behavior of the roasting process; when Taoukis et al. [56] states that five or six experimental temperatures are the practical optimum to obtain meaningfully narrow confidence limits in kinetic parameters $\left(E_{a}\right.$ and $k$ ). The values obtained from the fitted parameters in Matlab are given in Table 2 and consistent with previous studies $[26,28,41,57]$, in which the first-order kinetic model explains both TPC and epicatechin degradation at all temperatures; the $k$ value of epicatechin is higher than the $k$ value of TPC. These results suggest that the degradation of epicatechin is faster than the degradation of TPC. Roasting conditions of $130{ }^{\circ} \mathrm{C}$ and 10 min produced a lower percentage of epicatechin $(8.05 \pm 3.01 \%)$ and TPC $(10.98 \pm 6.04 \%)$ degradation. Many authors claim that these compounds are degraded by heat $[4,22,23,50]$. The most intense temperatures have caused significant degradation of the components; however, it was found that the epicatechin is more thermosensitive than TPC. This is explained by the greater $k$ value that epicatechin has compared to TPC; however, the chemical basis of this phenomenon must be studied.

Kinetic modeling may also use the influence of processing on critical quality parameters. Knowledge of degradation kinetics, including the reaction order, $E_{a}$ and $k$, is of great importance to predict food quality loss during thermal process treatments [58]. Food quality loss reactions described by the kinetic models were shown to follow Arrhenius (Equation (5)) behavior with temperature 
changes [56]. The $E_{a}$ for TPC was greater than the $E_{a}$ for epicatechin, this being the minimal value of energy that a specific collision between reagent molecules must achieve in order for a reaction to take place [59]. The epicatechin thus needs less energy than TPC to degrade it. The relative differences in $E_{a}$ values could be due to the different composition of the sample studied or to changes occurring in the samples during heating [58]. Olivares-Tenorio et al. [60] observed that catechin followed patterns of formation by epimerization and degradation, and experiments need to be devised to unravel these various reactions. Figure 1 shows that catechin reaction kinetics could be divided into a two order models: one for formation and the other for degradation, where the highest catechin formation was at $170{ }^{\circ} \mathrm{C}$ and $30 \mathrm{~min}(\mathbf{8 4 . 9 0} \pm \mathbf{3 7 . 9 0 \%})$, followed by treatments at $190{ }^{\circ} \mathrm{C}$ and $150{ }^{\circ} \mathrm{C}$. The largest catechin formation occurs in the first $30 \mathrm{~min}$ of roasting at any of the aforementioned temperatures. The epimerization from epicatechin to catechin due to technological treatment (heat) has often been postulated. Only a few publications have confirmed this reaction by enantioseparation. The reaction mechanism is not fully clarified, but it is assumed that ring opening occurs at position C-2 of the oxygenated ring, and reclosing leads to the atypical enantiomers. High temperatures, particularly when combined with alkaline conditions, accelerate the epimerization reaction [42]. Figure 1 shows that at 90 and $110^{\circ} \mathrm{C}$ there is only catechin degradation; subsequently, the formation of catechin begins slowly from $130{ }^{\circ} \mathrm{C}$, reaching its highest point at $190^{\circ} \mathrm{C}$. The treatment at $200{ }^{\circ} \mathrm{C}$ only shows a degradation pattern. It is assumed that the $k$ for catechin formation kinetics will be greater at $190^{\circ} \mathrm{C}$ for $30 \mathrm{~min}$, after which the degradation kinetics will take place at a high $k$. An enantoseparation reaction will occur to a greater extent for $30 \mathrm{~min}$ when the Criollo cocoa beans are roasted at 150,170 , or $190^{\circ} \mathrm{C}$.

\section{Conclusions}

The roasting process of Criollo cocoa allowed for a higher formation of catechin in the first $30 \mathrm{~min}$ of the process at $170{ }^{\circ} \mathrm{C}$, followed by degradation to minimum levels at $200{ }^{\circ} \mathrm{C}$, while the epicatechin showed greater susceptibility to treatment than the TPC and the catechin. Likewise, the degradation data of TPC and epicatechin are better suited to a first-order kinetic reaction as the temperature increases. Although it is true that the roasting stage is essential for the development of the aromas of chocolate, this also affects the polyphenolic content and monomeric flavan-3-ol of cocoa beans and thus the final chocolate product; therefore, roasting at moderate temperatures is necessary to obtain minimal degradation of cocoa phenolic compounds and consequently antioxidant properties. Likewise, with epicatechin being part of the total phenolic compounds, its degradation percentage is higher. This is explained by its kinetics; however, its chemical explanation for future work is pending.

Author Contributions: Conceptualization, E.M.C.-A. and F.P.C.-T.; methodology, E.F.-R. and S.G.C.-Q.; software, E.M.C.-A.; formal analysis, E.M.C.-A. and F.P.C.-T.; investigation, E.F.-R.; writing-original draft preparation, E.F.-R.; writing-review and editing, E.M.C.-A., R.S., and F.P.C.-T.; supervision, F.P.C.-T. All authors have read and agreed to the published version of the manuscript.

Funding: This research was funded by Project $N^{\circ} 16808-2016 /$ PROYECTO-CACAO, of the Programa Nacional de Innovación Agraria (PNIA) of the Instituto Nacional de Innovación Agraria of the Peruvian Government, the Universidad Nacional Toribio Rodríguez de Mendoza de Amazonas, and the Pontificia Universidad Católica del Perú.

Acknowledgments: A special acknowledgement to Multi-Service Cooperative APROCAM for the permission for the use of their facilities.

Conflicts of Interest: The authors declare that there is no conflict of interest.

\section{References}

1. Żyżelewicz, D.; Budryn, G.; Oracz, J.; Antolak, H.; Kręgiel, D.; Kaczmarska, M. The effect on bioactive components and characteristics of chocolate by functionalization with raw cocoa beans. Food Res. Int. 2018, 113, 234-244. [CrossRef] [PubMed]

2. Castro-Alayo, E.M.; Idrogo-Vásquez, G.; Siche, R.; Cardenas-Toro, F.P. Formation of aromatic compounds precursors during fermentation of Criollo and Forastero cocoa. Heliyon 2019, 5, e01157. [CrossRef] 
3. Ascrizzi, R.; Flamini, G.; Tessieri, C.; Pistelli, L. From the raw seed to chocolate: Volatile profile of Blanco de Criollo in different phases of the processing chain. Microchem. J. 2017, 133, 474-479. [CrossRef]

4. Żyżelewicz, D.; Krysiak, W.; Oracz, J.; Sosnowska, D.; Budryn, G.; Nebesny, E. The influence of the roasting process conditions on the polyphenol content in cocoa beans, nibs and chocolates. Food Res. Int. 2016, 89, 918-929. [CrossRef]

5. Stanley, T.H.; Van Buiten, C.B.; Baker, S.A.; Elias, R.J.; Anantheswaran, R.C.; Lambert, J.D. Impact of roasting on the flavan-3-ol composition, sensory-related chemistry, and in vitro pancreatic lipase inhibitory activity of cocoa beans. Food Chem. 2018, 255, 414-420. [CrossRef] [PubMed]

6. Oracz, J.; Nebesny, E. Influence of roasting conditions on the biogenic amine content in cocoa beans of different Theobroma cacao cultivars. Food Res. Int. 2014, 55, 1-10. [CrossRef]

7. Hu, Y.; Pan, Z.J.; Liao, W.; Li, J.; Gruget, P.; Kitts, D.D.; Lu, X. Determination of antioxidant capacity and phenolic content of chocolate by attenuated total reflectance-Fourier transformed-infrared spectroscopy. Food Chem. 2016, 202, 254-261. [CrossRef]

8. Sacchetti, G.; Ioannone, F.; De Gregorio, M.; Di Mattia, C.; Serafini, M.; Mastrocola, D. Non enzymatic browning during cocoa roasting as affected by processing time and temperature. J. Food Eng. 2016, 169, 44-52. [CrossRef]

9. Nascimento, M.M.; Santos, H.M.; Coutinho, J.P.; Lôbo, I.P.; da Silva Junior, A.L.S.; Santos, A.G.; de Jesus, R.M. Optimization of chromatographic separation and classification of artisanal and fine chocolate based on its bioactive compound content through multivariate statistical techniques. Microchem. J. 2020, 152, 104342. [CrossRef]

10. Steinberg, F.M.; Bearden, M.M.; Keen, C.L. Cocoa and chocolate flavonoids: Implications for cardiovascular health. J. Am. Diet. Assoc. 2003, 103, 215-223. [CrossRef]

11. Do Carmo Brito, B.D.N.; Campos Chisté, R.; Da Silva Pena, R.; Abreu Gloria, M.B.; Santos Lopes, A. Bioactive amines and phenolic compounds in cocoa beans are affected by fermentation. Food Chem. 2017, 228, 484-490. [CrossRef] [PubMed]

12. Alean, J.; Chejne, F.; Rojano, B. Degradation of polyphenols during the cocoa drying process. J. Food Eng. 2016, 189, 99-105. [CrossRef]

13. Wang, Y.; Feltham, B.A.; Suh, M.; Jones, P.J.H. Cocoa flavanols and blood pressure reduction: Is there enough evidence to support a health claim in the United States? Trends Food Sci. Technol. 2019, 83, 203-210. [CrossRef]

14. Alañón, M.E.; Castle, S.M.; Siswanto, P.J.; Cifuentes-Gómez, T.; Spencer, J.P.E. Assessment of flavanol stereoisomers and caffeine and theobromine content in commercial chocolates. Food Chem. 2016, 208, 177-184. [CrossRef] [PubMed]

15. Fayeulle, N.; Vallverdu-Queralt, A.; Meudec, E.; Hue, C.; Boulanger, R.; Cheynier, V.; Sommerer, N. Characterization of new flavan-3-ol derivatives in fermented cocoa beans. Food Chem. 2018, 259, 207-212. [CrossRef] [PubMed]

16. Ioannone, F.; Di Mattia, C.D.; De Gregorio, M.; Sergi, M.; Serafini, M.; Sacchetti, G. Flavanols, proanthocyanidins and antioxidant activity changes during cocoa (Theobroma cacao L.) roasting as affected by temperature and time of processing. Food Chem. 2015, 174, 256-262. [CrossRef]

17. Krysiak, W. Influence of roasting conditions on coloration of roasted cocoa beans. J. Food Eng. 2006, 77, 449-453. [CrossRef]

18. Andres-Lacueva, C.; Monagas, M.; Khan, N.; Izquierdo-Pulido, M.; Urpi-Sarda, M.; Permanyer, J.; Lamuela-Raventós, R.M. Flavanol and Flavonol Contents of Cocoa Powder Products: Influence of the Manufacturing Process. J. Agric. Food Chem. 2008, 56, 3111-3117. [CrossRef]

19. Martín, M.A.; Ramos, S. Cocoa polyphenols in oxidative stress: Potential health implications. J. Funct. Foods 2016, 27, 570-588. [CrossRef]

20. Martín, M.Á.; Ramos, S. Health beneficial effects of cocoa phenolic compounds: A mini-review. Curr. Opin. Food Sci. 2017, 14, 20-25. [CrossRef]

21. Della Pelle, F.; Blandón-Naranjo, L.; Alzate, M.; Del Carlo, M.; Compagnone, D. Cocoa powder and catechins as natural mediators to modify carbon-black based screen-printed electrodes. Application to free and total glutathione detection in blood. Talanta 2020, 207, 120349. [CrossRef] [PubMed]

22. Hii, C.L.; Menon, A.S.; Chiang, C.L.; Sharif, S. Kinetics of hot air roasting of cocoa nibs and product quality. J. Food Process Eng. 2017, 40, e12467. [CrossRef] 
23. Afoakwa, E. Roasting effects on phenolic content and free radical scavening actiivities of pulp preconditioned and fermented (Theobroma cacao) beans. Afr. J. Food Agric. Nutr. Dev. 2015, 15, 9635-9650.

24. Van Durme, J.; Ingels, I.; De Winne, A. Inline roasting hyphenated with gas chromatography-mass spectrometry as an innovative approach for assessment of cocoa fermentation quality and aroma formation potential. Food Chem. 2016, 205, 66-72. [CrossRef]

25. Hu, S.; Kim, B.-Y.; Baik, M.-Y. Physicochemical properties and antioxidant capacity of raw, roasted and puffed cacao beans. Food Chem. 2016, 194, 1089-1094. [CrossRef]

26. Teh, Q.T.M.; Tan, G.L.Y.; Loo, S.M.; Azhar, F.Z.; Menon, A.S.; Hii, C.L. The Drying Kinetics and Polyphenol Degradation of Cocoa Beans: Cocoa Drying and Polyphenol Degradation. J. Food Process Eng. 2016, 39, 484-491. [CrossRef]

27. Hii, C.L.; Law, C.L.; Cloke, M.; Suzannah, S. Thin layer drying kinetics of cocoa and dried product quality. Biosyst. Eng. 2009, 102, 153-161. [CrossRef]

28. Kyi, T.M.; Daud, W.R.W.; Mohammad, A.B.; Wahid Samsudin, M.; Kadhum, A.A.H.; Talib, M.Z.M. The kinetics of polyphenol degradation during the drying of Malaysian cocoa beans. Int. J. Food Sci. Technol. 2005, 40, 323-331. [CrossRef]

29. Summa, C.; Raposo, F.C.; McCourt, J.; Scalzo, R.L.; Wagner, K.-H.; Elmadfa, I.; Anklam, E. Effect of roasting on the radical scavenging activity of cocoa beans. Eur. Food Res. Technol. 2006, 222, 368-375. [CrossRef]

30. Jonfia-Essien, W.A.; West, G.; Alderson, P.G.; Tucker, G. Phenolic content and antioxidant capacity of hybrid variety cocoa beans. Food Chem. 2008, 108, 1155-1159. [CrossRef]

31. Singleton, V.; Orthofer, R.; Lamuela-Raventos, R. Analysis of total phenols and other oxidation substrates and antioxidants by means of Folin Ciocalteau reagent. In Methods in Enzymology; Academic Press: Cambridge, UK, 1999; pp. 152-178.

32. Payne, M.J.; Hurst, W.J.; Miller, K.B.; Rank, C.; Stuart, D.A. Impact of Fermentation, Drying, Roasting, and Dutch Processing on Epicatechin and Catechin Content of Cacao Beans and Cocoa Ingredients. J. Agric. Food Chem. 2010, 58, 10518-10527. [CrossRef]

33. Van Boekel, M.A.J.S.; Tijskens, L.M.M. Kinetic modelling. In Food Process Modelling; Woodhead Publishing Limited: Cambridge, UK, 2001; pp. 35-59. ISBN 978-1-85573-565-1.

34. Rabeler, F.; Feyissa, A.H. Kinetic Modeling of Texture and Color Changes During Thermal Treatment of Chicken Breast Meat. Food Bioprocess Technol. 2018, 11, 1495-1504. [CrossRef]

35. García-Alamilla, P.; Lagunes-Gálvez, L.M.; Barajas-Fernández, J.; García-Alamilla, R. Physicochemical Changes of Cocoa Beans during Roasting Process. J. Food Qual. 2017, 2017, 1-11. [CrossRef]

36. Hurst, W.J.; Krake, S.H.; Bergmeier, S.C.; Payne, M.J.; Miller, K.B.; Stuart, D.A. Impact of fermentation, drying, roasting and Dutch processing on flavan-3-ol stereochemistry in cacao beans and cocoa ingredients. Chem. Cent. J. 2011, 5, 53. [CrossRef] [PubMed]

37. Baghdadi, Y.M.; Hii, C.L. Mass transfer kinetics and effective diffusivities during cocoa roasting. J. Eng. Sci. Technol. 2017, 12, 127-137.

38. Menon, A.S.; Hii, C.L.; Law, C.L.; Shariff, S.; Djaeni, M. Effects of drying on the production of polyphenol-rich cocoa beans. Dry. Technol. 2017, 35, 1799-1806. [CrossRef]

39. Wang, H.; Helliwell, K.; You, X. Isocratic elution system for the determination of catechins, caffeine and gallic acid in green tea using HPLC. Food Chem. 2000, 68, 115-121. [CrossRef]

40. Martins, L.M.; Sant'Ana, A.S.; Iamanaka, B.T.; Berto, M.I.; Pitt, J.I.; Taniwaki, M.H. Kinetics of aflatoxin degradation during peanut roasting. Food Res. Int. 2017, 97, 178-183. [CrossRef]

41. Molaveisi, M.; Beigbabaei, A.; Akbari, E.; Noghabi, M.S.; Mohamadi, M. Kinetics of temperature effect on antioxidant activity, phenolic compounds and color of Iranian jujube honey. Heliyon 2019, 5, e01129. [CrossRef]

42. Kothe, L.; Zimmermann, B.F.; Galensa, R. Temperature influences epimerization and composition of flavanol monomers, dimers and trimers during cocoa bean roasting. Food Chem. 2013, 141, 3656-3663. [CrossRef]

43. Wollgast, J.; Anklam, E. Review on polyphenols in Theobroma cacao: Changes in composition during the manufacture of chocolate and methodology for identification and quantification. Food Res. Int. 2000, 33, 423-447. [CrossRef]

44. Quelal-Vásconez, M.A.; Lerma-García, M.J.; Pérez-Esteve, É.; Arnau-Bonachera, A.; Barat, J.M.; Talens, P. Changes in methylxanthines and flavanols during cocoa powder processing and their quantification by near-infrared spectroscopy. LWT 2020, 117, 108598. [CrossRef] 
45. Kim, H.; Keeney, P.G. (-)-Epicatechin Content in Fermented and Unfermented Cocoa Beans. J. Food Sci. 1984, 49, 1090-1092. [CrossRef]

46. Mazor Jolić, S.; Radojčić Redovniković, I.; Marković, K.; Ivanec Šipušić, Đ.; Delonga, K. Changes of phenolic compounds and antioxidant capacity in cocoa beans processing: Changes of phenolic in cocoa beans processing. Int. J. Food Sci. Technol. 2011, 46, 1793-1800. [CrossRef]

47. Peláez, P.; Bardón, I.; Camasca, P. Methylxanthine and catechin content of fresh and fermented cocoa beans, dried cocoa beans, and cocoa liquor. Sci. Agropecu. 2016, 7, 355-365. [CrossRef]

48. Prakash, M.; Basavaraj, B.V.; Chidambara Murthy, K.N. Biological functions of epicatechin: Plant cell to human cell health. J. Funct. Foods 2019, 52, 14-24. [CrossRef]

49. Miller, K.B.; Hurst, W.J.; Flannigan, N.; Ou, B.; Lee, C.Y.; Smith, N.; Stuart, D.A. Survey of Commercially Available Chocolate- and Cocoa-Containing Products in the United States. 2. Comparison of Flavan-3-ol Content with Nonfat Cocoa Solids, Total Polyphenols, and Percent Cacao. J. Agric. Food Chem. 2009, 57, 9169-9180. [CrossRef]

50. Djikeng, F.T.; Teyomnou, W.T.; Tenyang, N.; Tiencheu, B.; Morfor, A.T.; Touko, B.A.H.; Houketchang, S.N.; Boungo, G.T.; Karuna, M.S.L.; Ngoufack, F.Z.; et al. Effect of traditional and oven roasting on the physicochemical properties of fermented cocoa beans. Heliyon 2018, 4, e00533. [CrossRef]

51. Suazo, Y.; Davidov-Pardo, G.; Arozarena, I. Effect of Fermentation and Roasting on the Phenolic Concentration and Antioxidant Activity of Cocoa from Nicaragua: Effect of Process on Cocoa from Nicaragua. J. Food Qual. 2014, 37, 50-56. [CrossRef]

52. Schroeter, H.; Heiss, C.; Balzer, J.; Kleinbongard, P.; Keen, C.L.; Hollenberg, N.K.; Sies, H.; Kwik-Uribe, C.; Schmitz, H.H.; Kelm, M. (-)-Epicatechin mediates beneficial effects of flavanol-rich cocoa on vascular function in humans. Proc. Natl. Acad. Sci. USA 2006, 103, 1024-1029. [CrossRef]

53. Lončarić, A.; Pablo Lamas, J.; Guerra, E.; Kopjar, M.; Lores, M. Thermal stability of catechin and epicatechin upon disaccharides addition. Int. J. Food Sci. Technol. 2018, 53, 1195-1202. [CrossRef]

54. Bernatova, I. Biological activities of (-)-epicatechin and (-)-epicatechin-containing foods: Focus on cardiovascular and neuropsychological health. Biotechnol. Adv. 2018, 36, 666-681. [CrossRef] [PubMed]

55. Oracz, J.; Nebesny, E.; Żyżelewicz, D. Changes in the flavan-3-ols, anthocyanins, and flavanols composition of cocoa beans of different Theobroma cacao L. groups affected by roasting conditions. Eur. Food Res. Technol. 2015, 241, 663-681. [CrossRef]

56. Taoukis, P.S.; Labuza, T.P.; Saguy, I.S. Kinetics of Food Deterioration and Shelf-Life Prediction. In Handbook of Food Engineering Practice; CRC Press: New York, NY, USA, 1997; pp. 366-408.

57. Henríquez, C.; Córdova, A.; Almonacid, S.; Saavedra, J. Kinetic modeling of phenolic compound degradation during drum-drying of apple peel by-products. J. Food Eng. 2014, 143, 146-153. [CrossRef]

58. Turturică, M.; Stănciuc, N.; Bahrim, G.; Râpeanu, G. Effect of thermal treatment on phenolic compounds from plum (prunus domestica) extracts-A kinetic study. J. Food Eng. 2016, 171, 200-207. [CrossRef]

59. Garvín, A.; Ibarz, R.; Ibarz, A. Kinetic and thermodynamic compensation. A current and practical review for foods. Food Res. Int. 2017, 96, 132-153. [CrossRef]

60. Olivares-Tenorio, M.-L.; Verkerk, R.; van Boekel, M.A.J.S.; Dekker, M. Thermal stability of phytochemicals, HMF and antioxidant activity in cape gooseberry (Physalis peruviana L.). J. Funct. Foods 2017, 32, 46-57. [CrossRef]

(C) 2020 by the authors. Licensee MDPI, Basel, Switzerland. This article is an open access article distributed under the terms and conditions of the Creative Commons Attribution (CC BY) license (http://creativecommons.org/licenses/by/4.0/). 